\title{
Factors Affecting Employee Fraud: A Study Among Private Companies in Jakarta
}

\author{
Yuniarwati Yuniarwati ${ }^{1 *}$ I Cenik Ardana ${ }^{1}$ Elizabeth Sugiarto D. ${ }^{1}$ \\ ${ }^{1}$ Faculty of Economics and Business, Universitas Tarumanagara, West Jakarta 11470, Indonesia \\ *Corresponding author. Email: yuniarwati@fe.untar.ac.id
}

\begin{abstract}
The increasing number of employee fraud has received great attention these days because it can have a negative impact on staff morale, increase company costs, and damage the company's reputation with the relevant stakeholders. There have been several theories of fraud that have emerged, including Cressey's fraud triangle theory, but many are of the view that the existing theories are only able to explain the triggers of fraud, but are not sufficient as a tool to understand the phenomenon of fraud more comprehensively. There is a missing link in these theories, including the neglect of factors that can reduce fraud, such as ethics, religiosity, spirituality, and so on. This research tries to add personal ethics aspects to Cressey's fraud triangle theory and examines the influence of elements of the fraud triangle theory and personal ethics to employee fraud. The research design used primary data collected through a questionnaire distributed to employees of private companies in Jakarta in 2020. The number of questionnaires sent and returned was 115. Descriptive statistics and multiple regression tests used to data analysis. The results describe that only opportunity influenced positively and significantly to employee fraud; meanwhile, pressure, rationalization, and personal ethics do not have significant influences to employee fraud.
\end{abstract}

Keywords: fraud triangle theory, opportunity, pressure, rationality, personal ethics

\section{INTRODUCTION}

The increasing number of employee fraud has received great attention because it can have a negative impact on staff morale, increase company costs, and damage the company's reputation in the eyes of related stakeholders (Said, et al, [20]). Since "the Report to the Nations" was published by the Association of Certified Fraud Examiner (ACFE) in 1996, the employee fraud model has remained consistent through three major schemes that are more popularly known as the fraud tree: corruption, misuse of assets, and presentation of fake financial statements (ACFE, [2]).

Employee fraud that occurs in Indonesia can be seen from the results of the Indonesian Fraud Survey (SFI) in 2019 which showed a total loss of around Rp. 874.43 billion with an average loss of around Rp. 7,248 billion per case (ACFE Indonesia Chapter, [3]). The SFI results also reveal the organizations or institutions that are most disadvantaged by fraud are: government agencies (48.5\%), governmentowned companies / BUMN (31.8\%), private companies $(15.1 \%)$, non-profit organizations $(2.9 \%)$ ), and others $(1.7 \%)$. In terms of the type of fraud, corruption is in the first rank, followed by the misuse of assets in the second rank, and the issuance of false financial reports in the third rank.
Fraud in the business world has been studied extensively, and has produced several theories that can be used to explain the motivation for fraud (Said, et al, [20]). At least, three popular fraud theories have emerged, namely the Fraud Triangle Theory by Cressey in 1953, the Fraud Diamond Theory by Wolfe and Hermanson in 2004, and the Pentagon of Fraud Theory by Crowe in 2011 (Muhsin, Kardoyo, \& Nurkhin, [17]).

Although these three theories have received wide support from various parties, as expressed by several experts (Ergina \& Erturanb [9]; Abayomi [1]; Said, et al, [21]), these three theories only serve to explain the triggers of fraud, but are not sufficient as a tool to reduce, prevent, or negate the intentions and actions of fraud. There is a missing link in the three theories, namely the neglect of other elements that function to reduce, or negate the intentions and actions of fraud. These elements include personal ethics (Abayomi, [1]), or religiosity (Said, et al [20]), or spirituality (Purnamasaria \& Amaliah, [18]).

This research is a replication of Said, et al [20] ) to examine the effect of Cressey's Fraud Triangle Theory and personal ethics on employee fraud intentions. There are two main differences between this research and those carried out by Said, et al, namely: first, the added variables where Said et al used religiosity, while this study used personal ethics; second, the sample used by Said et al are members of the Malaysian police, while this study uses private company 
employees in Indonesia. It is hoped that by expanding the subject and object of research, and by integrating personal ethics into the existing fraud theory, it can more enrich the point of view of the phenomenon of fraud that occurs.

This study tries to investigate the influence of the elements in Cressey's fraud theory: opportunity, pressure, and rationalization, as well as personal ethics on employee fraud. The formulation of the problem is: (1) is there a positive effect of opportunity on employee fraud; (2) is there a positive effect of pressure on employee fraud (3) is there a positive effect of rationalization on employee fraud; (4) whether there is a negative effect of personal ethics on employee fraud.

The results of this study, which integrate the elements of a damper as well as a trigger for fraud, will provide practical benefits for policy makers in an organizational entity in an effort to establish and implement a policy that is both preventive and repressive against any form of fraud.

\section{LITERATURE REVIEW}

\subsection{The Theory of Fraud}

The word "theory" means "contemplation." Scientists tend to disagree about the finer points of a theory, but all seem to agree that a theory is a description of a phenomenon and its variable that are used to explain or predict (Thomas [25]). The theory of fraud means an interaction of several variables used to explain the phenomenon of fraud. There have been many theories of fraud, but the most popular is the fraud triangle theory expressed by Cressey in 1953 (Malimage [15]). The fraud triangle theory is formed by three elements: opportunity, pressure, and rationalization.

\subsubsection{Fraud}

Fraud is a concept whose meaning is very broad and its characteristics are often unrecognizable and only realized after it is too late (Vousinas [26]). Coenen (Machado \& Gartner [14]) defines fraud as a deliberately falsified representation of material and which causes harm to the victim. The Institute of Internal Auditors [24] defines fraud as an illegal act characterized by fraud, concealment, or breach of trust. Ruin (Said, et al, [21] said that fraud is an action by one party to obtaining a profit by avoiding its obligation or causing financial or non-financial losses to other parties. The Association of Certified Fraud Examiners (Bonsu, et al [5]) says fraud is like using deception to make personal gain for oneself dishonestly and creating harm for others.

The Association of Certified Fraud Examiners [2] classifies fraud into three main classifications: asset misappropriation, corruption, and the presentation of fraudulent financial statements. Misuse of assets involves theft or misuse of organizational resources by employees who employ them. The presentation of false financial statements is the act of an offender who deliberately causes material misstatement or negligence in the organization's financial statements, while corruption includes violations such as bribery, conflict of interest and extortion.

Homer [12] has reviewed the literature on the ability of Cressey's fraud triangle theory in explaining various phenomena of fraud in the international sphere. Of the studies included, there are 32 studies found support for at least one element of the fraud triangle and 27 studies found support for all three elements. Overall, this research has shown that the fraud triangle receives support from a wide range of studies, industry, and countries in general.

\subsubsection{Opportunity}

Opportunity refers to the circumstances that fraud can be occur. Conditions that make the opportunities for fraud include weak internal controls, absence of top management commitment, and inadequate accounting policies (CFI [6]). Opportunity is a situation that triggers a person to commit a fraudulent act (Evana, et al [8]). Opportunity is where a person feels a combination conditions that allow him to commit fraud and will not be detected (Istifadah \& Senjani [13]). Research conducted by Anfas, Mahdi, \& Umasugi [4] revealed that opportunities do not affect fraud, while research conducted by Christian, Basri, \& Arafah [7]; Maria \& Gudono [16] reveal that opportunities have a significant effect on fraud.

\subsubsection{Pressure}

Pressure is a compelling condition that includes targets to be achieved or difficult conditions, such as family members who are sick (Ramadhan [19]). Pressure is anything that causes someone to commit fraud, such as medical bills, expensive lifestyle, and drug addiction problems (Muhsin, Kardoyo, \& Nurkhin [17]). It can be concluded that pressure is a compelling condition that includes a target to be achieved, or difficult financial conditions, or individual egocentric motivation. Research conducted by Anfas, Mahdi, \& Umasugi [4] revealed that pressure has no effect on academic fraud, while research conducted by Christian, Basri, \& Arafah [7]; Maria \& Gudono [16] reveal that pressure have a significant effect on fraud.

\subsubsection{Rationalization}

Rationalization is a thought that justifies an action as natural behavior, which can be accepted in normal society (Sujana, Yasa, \& Wahyuni [22]). Slezak (Said, et al [21]) says rationalization is a way to legitimize an action that is not in accordance with one's beliefs. Another view says that rationalization is a personal justification for acting for themselves (Istifadah \& Senjani [13]). It can be concluded that rationalization is a justification for an action that is actually not in accordance with one's beliefs as behavior that is considered natural or acceptable to normal society. Research conducted by Anfas, Mahdi, \& Umasugi [4]; Christian, Basri, \& Arafah [7]; Maria \& Gudono [16] reveal that rationalizaion have a significant effect on fraud. 


\subsubsection{Personal Ethics}

Ethics is the set of norms that govern individual moral behavior in society and must be observed through the habits that exist in society. Personal ethics, as a form of special ethics that govern one's actions through the moral principles and rules (Abayomi [1]). Ethics are the principles and moral values that govern the behavior of a person or group regarding what is right or wrong (Fernandhytia \& Muslichah [10]). Ethics is an agreed standard of what is wanted and unwanted, about the right and wrong behavior of a person, group or entity (Sujeewa, et al [23]). Personal ethics can be formulated as principles and moral values that regulate the behavior of a person or group regarding what is right and wrong. Said, et al, [21]; Fernandhytia and Muslichah [10] report that ethical values have a significant negative effect on fraud.

\subsection{Hypothesis Developments}

\subsubsection{The Effect of Opportunities on Employee Fraud}

Opportunity arises because there are circumstances that make fraud occur. Opportunities in general can be caused by gaps in internal control weaknesses. The greater the opportunities for fraud in the workplace will increase one's intentions and actions to cheat. Based on this reasoning, the first hypothesis is as follows:

$\mathrm{H}_{1}$ : Opportunities have a positive and significant effect on Employee Fraud.

\subsubsection{The Effect of Pressure on Employee Fraud}

Pressure is a situation that forces a person to include a target to be achieved or a difficult condition, such as a sick family member. Pressure can be in the form of outside pressure to meet certain income targets, or personal financial needs, someone's luxurious lifestyle, and so on. An element of pressure will result in a manager or employee committing fraud. Based on this understanding, the second hypothesis can be formulated as follows:

$\mathrm{H}_{2}$ : Pressure has a positive and significant effect on Employee Fraud

\subsubsection{The Effect of Rationalization on Employee Fraud}

Rationalization is a justification that is not in accordance with one's beliefs. Rationalization occurs when a person reinterprets his actions as morally acceptable. In general, people tend to make a justification of a crime before deciding to commit a crime. Based on this understanding, the third hypothesis can be formulated as follows:

$\mathrm{H}_{3}$ : Rationalization has a positive and significant effect on Employee Fraud

\subsubsection{The Effect of Personal Ethics on Employee Fraud}

Personal ethics is an agreed standard of what is right and wrong of a person, group or entity behavior. Ethics guides employee actions based on moral principles. Ethical values that are embedded in a person will be able to reduce one's intentions and actions to cheat. The weaker a person's moral principles and values, the stronger that person's intentions and actions are to cheat. Based on this understanding, the following hypothesis can be formulated:

$\mathrm{H}_{4}$ : Personal Ethics has a negative and significant effect on Employee Fraud

\section{RESEARCH METHOD}

The population in this study were employees of private companies in Jakarta. The sample of this research is convenience sampling by taking samples from employees of private companies who are currently studying in the Accounting Professional Education Program, the Master of Accounting Study Program, and the Master of Management Study Program at Tarumanagara University, and employee class program of the University of Pelita Harapan Jakarta. The research data was obtained by distributing questionnaires directly to respondents using google form. The number of questionnaires sent and returned was 115 . Operationalization of Research Variables can be seen in Table 1.

Table 1 Operationalization of Research Variables

\begin{tabular}{|l|l|l|l|l|}
\hline No. & \multicolumn{1}{|c|}{ Variable } & \multicolumn{1}{c|}{ Indicators } & \multicolumn{1}{c|}{ Scale } & \multicolumn{1}{c|}{ Reference } \\
\hline 1 & Employee fraud & 9 questions & Ordinal & $\begin{array}{l}\text { Said, et al (2017); } \\
(2018)\end{array}$ \\
& (Dependent Variable) & & & Ordinal \\
& Opportunity & 8 questions; & Ordinal & $(2018)$ \\
& Pressure & 8 questions; & Ordinal & \\
& Rasionalization & 8 questions; & Ordinal & \\
& Personal Ethics & 8 questions & & \\
& (Independent Variables) & & & \\
\hline
\end{tabular}


Hypothesis testing techniques in this study using multiple regression tests with SPSS software. Before testing the research model, first the validity and reliability tests were carried out as well as the classic requirements test consisting of the normality test, multicollinearity test, and heteroscedasticity test.

\section{FINDINGS AND DISCUSSIONS}

The testing process in this research model includes testing the reliability and validity of research instruments, data normality, classical assumptions, and hypotheses on the effect of Pressure, Opportunity, Rationalization, and Personal Ethics on Employee Fraud. Reliability happened if the Cronbach $\alpha$ value is above 0.6 , while validity happened if the calculated $r$ value (Corrected Item-Total Correlation) is less than the r-table value [11]. The r-table value with $\mathrm{df}$ $(115-2)$ and $\operatorname{sig}=0.05$ is 0.1832 . Instrument reliability testing can be seen in table 2. Cronbach's $\alpha$ values for all variables are greater than 0.6 so that the research instrument can be said to be reliable.

Table 2 Reliability Test

\begin{tabular}{|c|c|c|c|c|}
\hline No & Variable & Cronbach's $\alpha$ & $\begin{array}{c}\text { Cronbach's } \alpha \text { Based on } \\
\text { Standardized Items }\end{array}$ & Nof Items \\
\hline 1 & Employee Fraud $(E F)$ & 0.817 & 0.860 & 9 \\
\hline 2 & Personal Ethics $(P E)$ & 0.697 & 0.705 & 8 \\
\hline 3 & Pressure $(P R)$ & 0.771 & 0.779 & 8 \\
\hline 4 & Opportunity $(O P)$ & 0.865 & 0.869 & 8 \\
\hline 5 & Rationalization $(R A)$ & 0.731 & 0.727 & 8 \\
\hline
\end{tabular}

Instrument validity testing for Employee Fraud (EF), Pressure (PR), Opportunity (OP), Rationalization (RA), and
Personal Ethics (PE), respectively can be seen in the table 3a, 3b, 3c, 3d, 3e.

Table 3a Testing the Validity of Employee Fraud Instruments (EF)

Item-Total Statistics

\begin{tabular}{|c|c|c|c|c|c|}
\hline & $\begin{array}{l}\text { Scale Mean if } \\
\text { Item Deleted }\end{array}$ & $\begin{array}{l}\text { Scale Variance } \\
\text { if Item Deleted }\end{array}$ & $\begin{array}{c}\text { Corrected Item- } \\
\text { Total } \\
\text { Correlation }\end{array}$ & $\begin{array}{c}\text { Squared } \\
\text { Multiple } \\
\text { Correlation }\end{array}$ & $\begin{array}{l}\text { Cronbach's } \alpha \text { if } \\
\text { Item Deleted }\end{array}$ \\
\hline EF1 & 13.83 & 36.110 & .324 & .190 & .836 \\
\hline $\mathrm{EF} 2$ & 12.30 & 33.915 & .433 & .384 & .820 \\
\hline EF3 & 14.23 & 34.936 & .770 & .766 & .771 \\
\hline EF4 & 14.10 & 33.708 & .780 & .745 & .766 \\
\hline EF5 & 14.10 & 37.761 & .471 & .260 & .803 \\
\hline EF6 & 14.44 & 37.898 & .673 & .565 & .789 \\
\hline EF7 & 14.53 & 40.778 & .513 & .605 & .806 \\
\hline EF8 & 13.34 & 32.665 & .626 & .533 & .783 \\
\hline EF9 & 14.54 & 40.654 & .551 & .631 & .805 \\
\hline
\end{tabular}

Table 3b Testing the Validitas of Pressure Instrument (PR)

Item-Total Statistics

\begin{tabular}{|c|c|c|c|c|c|}
\hline & \multicolumn{5}{|c|}{ Item-Total Statistics } \\
\hline & $\begin{array}{l}\text { Scale Mean if } \\
\text { Item Deleted }\end{array}$ & $\begin{array}{l}\text { Scale Variance } \\
\text { if Item Deleted }\end{array}$ & $\begin{array}{c}\text { Corrected Item- } \\
\text { Total } \\
\text { Correlation }\end{array}$ & $\begin{array}{c}\text { Squared } \\
\text { Multiple } \\
\text { Correlation }\end{array}$ & $\begin{array}{l}\text { Cronbach's } \alpha \text { if } \\
\text { Item Deleted }\end{array}$ \\
\hline PR1 & 24.45 & 39.092 & .474 & .446 & .747 \\
\hline PR2 & 24.37 & 38.672 & .536 & .417 & .738 \\
\hline PR3 & 24.30 & 37.193 & .532 & .533 & .736 \\
\hline PR4 & 24.63 & 39.798 & .485 & .415 & .746 \\
\hline PR5 & 25.23 & 36.444 & .523 & .448 & .737 \\
\hline PR6 & 25.89 & 37.715 & .454 & .533 & .750 \\
\hline PR7 & 24.90 & 38.245 & .350 & .204 & .773 \\
\hline PR8 & 26.56 & 38.284 & .472 & .435 & .747 \\
\hline
\end{tabular}


Table 3c Testing the Validity of Opportunity Instrument (OP) Item-Total Statistics

\begin{tabular}{|c|c|c|c|c|c|}
\hline & $\begin{array}{l}\text { Scale Mean if } \\
\text { Item Deleted }\end{array}$ & $\begin{array}{l}\text { Scale Variance } \\
\text { if Item Deleted }\end{array}$ & $\begin{array}{c}\text { Corrected Item- } \\
\text { Total } \\
\text { Correlation }\end{array}$ & $\begin{array}{c}\text { Squared } \\
\text { Multiple } \\
\text { Correlation }\end{array}$ & $\begin{array}{l}\text { Cronbach's } \alpha \text { if } \\
\text { Item Deleted }\end{array}$ \\
\hline OP1 & 18.01 & 46.588 & .710 & .681 & .838 \\
\hline OP2 & 18.10 & 50.094 & .684 & .653 & .842 \\
\hline OP3 & 18.18 & 48.677 & .756 & .664 & .833 \\
\hline OP4 & 17.38 & 51.151 & .544 & .452 & .857 \\
\hline OP5 & 17.65 & 50.667 & .685 & .510 & .842 \\
\hline OP6 & 17.55 & 50.618 & .682 & .575 & .842 \\
\hline OP7 & 18.23 & 53.843 & .520 & .349 & .859 \\
\hline OP8 & 17.82 & 53.273 & .402 & .323 & .875 \\
\hline
\end{tabular}

Table 3d Testing the Validity of Rationalization Instrument (RA)

Item-Total Statistics

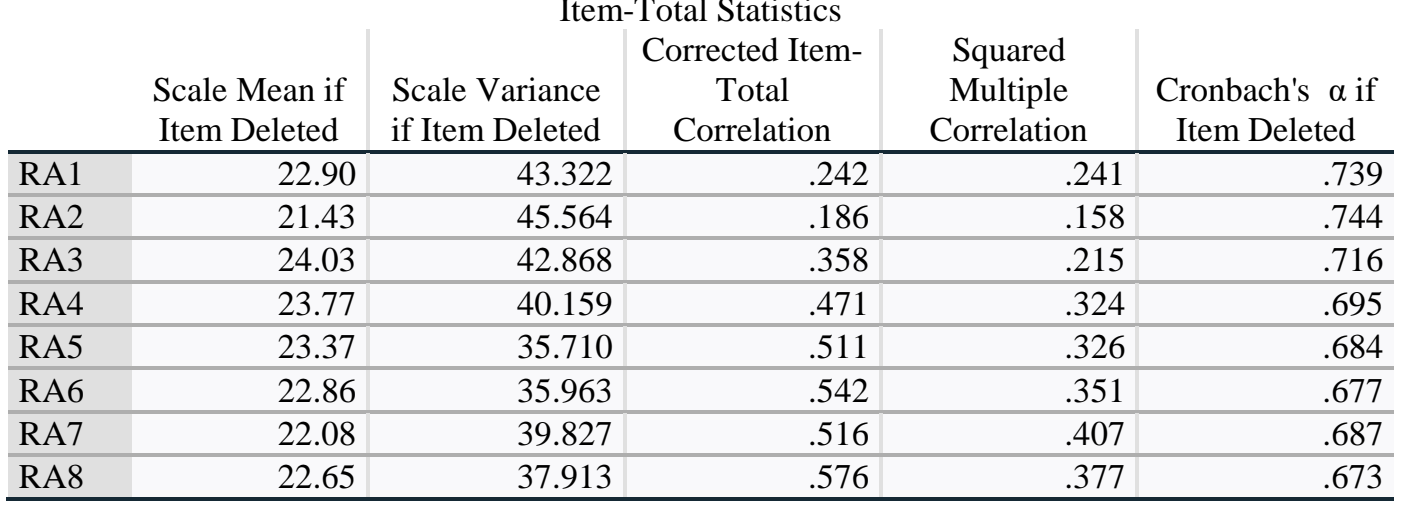

Table 3e Testing the Validity of Personal Ethics Instrument (PE) Item-Total Statistics

\begin{tabular}{|c|c|c|c|c|c|}
\hline & & & S & & \\
\hline & $\begin{array}{l}\text { Scale Mean if } \\
\text { Item Deleted }\end{array}$ & $\begin{array}{l}\text { Scale Variance } \\
\text { if Item Deleted }\end{array}$ & $\begin{array}{c}\text { Corrected Item- } \\
\text { Total } \\
\text { Correlation }\end{array}$ & $\begin{array}{c}\text { Squared } \\
\text { Multiple } \\
\text { Correlation }\end{array}$ & $\begin{array}{l}\text { Cronbach's } \alpha \text { if } \\
\text { Item Deleted }\end{array}$ \\
\hline PE1 & 29.27 & 35.006 & .194 & .169 & .723 \\
\hline PE2 & 27.35 & 35.369 & .367 & .261 & .673 \\
\hline PE3 & 29.00 & 31.526 & .501 & .415 & .640 \\
\hline PE4 & 28.00 & 34.298 & .397 & .268 & .666 \\
\hline PE5 & 28.48 & 30.585 & .618 & .438 & .613 \\
\hline PE6 & 28.67 & 31.662 & .473 & .418 & .647 \\
\hline PE7 & 27.76 & 35.642 & .356 & .253 & .675 \\
\hline PE8 & 27.67 & 36.697 & .258 & .179 & .693 \\
\hline
\end{tabular}

The results of the instrument validity test above show that all $r$-calculated values in the Corrected Item-Total Correlation column are greater than r-table 0.1832 so that the instrument can be declared valid.

The data normality test using the K-S test can be seen in Table 4. The test results show that the unstandardized residual significance value is 0.266 , still greater than the significance criteria of 0.05 , so that it can be concluded that the data has been normally distributed.
Table 4 One-Sample Kolmogorov-Smirnov Test

\begin{tabular}{|l|r|}
\hline & \multicolumn{2}{|c|}{$\begin{array}{c}\text { Unstandardized } \\
\text { Residual }\end{array}$} \\
\hline $\mathrm{N}$ & 115 \\
Kolmogorov-Smirnov Z & 1.004 \\
Asymp. Sig (2-tailed) & 0.266 \\
Monte Carlo Sig. (2-tailed): & 0.249 \\
$\quad$ Sig & \\
$\quad$ 95\% Confidence Interval & 0.241 \\
$\quad$ Lower Bound & 0.258 \\
$\quad$ Upper Bound & \\
\hline
\end{tabular}


The classic assumption test includes multicollinearity test and heteroscedasticity test. The multicollinearity test can be seen in Table 5a. The Tolerance values of all variables are still above 0.10 , or the VIF values of all variables are still below 10. This means free from multicollinearity problem between the independent variables.

Tabel 5a Classical Assumption-Multicollinearity Test

\begin{tabular}{|c|c|c|}
\hline Model & \multicolumn{2}{|c|}{ Colinearity Statistics } \\
\hline & Tolerance & VIF \\
\hline 1 (Constant) & & \\
PE & 0.956 & 1.046 \\
PR & 0.931 & 1.074 \\
OP & 0.771 & 1.297 \\
RA & 0.773 & 1.293 \\
\hline
\end{tabular}

The heteroscedasticity test can be seen in Table $5 \mathrm{~b}$. The significance values of all variables are 1,000, still above the 0.05 criterion, so that it can be concluded free from heteroscedasticity problem in this research data.

Tabel 5b Classical Assumption - Heteroscedasticity Test with Park-Test

\begin{tabular}{|c|c|}
\hline Model & Sig. \\
\hline 1 (Constant) & 1.000 \\
PE & 1.000 \\
PR & 1.000 \\
OP & 1.000 \\
RA & 1,000 \\
\hline
\end{tabular}

The significance value on the $\mathrm{F}$ test shows a number of 0.000 which is smaller than 0.05 . This means that the regression model consisting of the following variables: RA, $\mathrm{PE}, \mathrm{PR}$, and $\mathrm{OP}$, is appropriate to predict the dependent variable: EF. The Adjusted R Square value is 0.246. This means that the independent variables are able to explain $24.6 \%$ of the variance of the Employee fraud (EF), and the remaining $75,4 \%$ is influenced by other variables outside this research model. The results of hypothesis testing of the effect of Personal Ethics (PE), Pressure (PR), Opportunity (OP), and Rationalization (RA) partially on Employee Fraud (EF) can be seen in Table 6.

Table 6 The Results of t-Test

Coefficients $^{\mathrm{a}}$

\begin{tabular}{|c|r|c|c|c|}
\hline Model & \multicolumn{2}{|c|}{$\begin{array}{c}\text { Unstandardized } \\
\text { Coefficients }\end{array}$} & t & \multirow{2}{*}{ sig } \\
\cline { 2 - 3 } & $\mathrm{B}$ & $\begin{array}{c}\text { Std. } \\
\text { Error }\end{array}$ & & \\
\hline 1 (Constant) & 0.587 & 0.407 & 1.440 & 0.153 \\
PE & -0.018 & $0 / 076$ & -0.229 & 0.819 \\
PR & 0.015 & $0 / 072$ & $0 / 204$ & 0.839 \\
OP & $0 / 344$ & 0.069 & 5.012 & 0.000 \\
RA & 0.090 & 0.078 & 1.160 & 0.248 \\
\hline
\end{tabular}

a. Dependent Variable: EF
Coefficient $\mathrm{B}$ of the variable $\mathrm{PE}$ with $\mathrm{EF}$ is negative (0.018 ) and the significance value is 0.819 . The coefficient B value of (-0.018) implies that the direction of the relationship is negative, but the degree of the relationship is very weak. The significance value is 0.819 , is greater than 0.05 , indicating that the influence of the PE on the EF is not significant. It can be concluded that the first hypothesis: Personal Ethics has a negative and significant effect on Employee Fraud is not supported by empirical evidence. This study cannot support the research results done by Abayomi [1]; Said, et al [21] who reveal that PE has a negative and significant effect on EF, but this research is in accordance with Istifadah \& Senjani ([13] which states that that PE does not influence the tendency to fraud.

The coefficient $\mathrm{B}$ of the $\mathrm{PR}$ with the $\mathrm{EF}$ is positive at 0.015 , and the significance value is 0.839 . A positive coefficient $B$ value of 0.015 implies that the relationship is positive, but the degree of the relationship is very weak. The significance value is 0.839 , which is greater than the significance criteria of 0.05 , indicating that the influence of the PR on the EF is not significant. This study cannot support the research results done by Abayomi [1]; Said, et al [21]; Said, et al [20]; Sujeewa, et al [23], which revealed that PR has a positive and significant effect on EF, but this research is in line with the results of research done by Anfas, Mahdi, \& Umasugi [4] which states that PR has no significant effect on EF.

The coefficient $\mathrm{B}$ of the OP with the EF is positive at 0.344 , and the significance value is 0.000 . The positive coefficient $B$ value of 0.344 implies that the relationship direction is positive and sufficient. The significance value of 0.000 , which is smaller than the significance criteria of 0.05 , indicates that the influence of the $\mathrm{OP}$ on the $\mathrm{EF}$ is significant. It can be concluded that the third hypothesis: Opportunity has a positive and significant effect on Employee Fraud is supported by empirical evidence. The results of this study strengthen Said, et al [21]; Said, et al [20]; Istifadah \& Senjani [13] .

The coefficient $\mathrm{B}$ of the RA on the EF is positive at 0.090, and the significance value is 0.248 . A positive coefficient $B$ value of 0.090 implies a positive relationship between the $\mathrm{RA}$ and the EF, but the degree of the relationship is very weak. The significance value of 0.248 , which is greater than the significance criteria of 0.05 , indicates that the influence of the RA on the EF is not significant. The results of this study do not support Said, et al [21]; Said, et al [20]; Istifadah \& Senjani [13], which revealed that RA has a positive and significant effect on EF.

This study supports Homer's statement (Homer[12] ) in examining the ability of Cressey's fraud triangle theory to explain various phenomena of fraud which reveals that at least one element in Cressey's fraud triangle theory is able to predict the occurrence of fraud.

This study is not fully successful in providing empirical evidence on the hypothesis that PE has a negative and significant effect on EF. There is empirical evidence that personal ethics is negatively related to Employee Fraud; however, seen from its significance value, the effect of PE on EF is not significant. Many factors influence the 
relationship between personal ethics and employee fraud and this issue requires further investigation.

\section{CONCLUSIONS}

The results show that only opportunity has a significant effect on employee fraud, while pressure, rationalization and personal ethics have no effect on employee fraud. This study strengthens Homer's conclusion that at least one variable in Cressey's fraud triangle model (pressure, opportunity, rationalization) is a predictor of fraud. This study found that there was a negative correlation between personal ethics and employee fraud, but the effect of personal ethics on fraud was not significant. Many factors influence the relationship between personal ethics and employee fraud and this issue requires further investigation. There are several limitations in this study, including the limited number of samples, and as far as is known, a standardized ethical measurement model is not yet available. There are several suggestions for further research, including expanding the research sample and testing other models of ethical measurement.

Despite its limitations, the results of this study, which integrate the elements of a damper as well as a trigger for fraud, will provide practical benefits for policy makers in an organizational entity in an effort to establish and implement a policy that is both preventive and repressive against any form of fraud.

\section{ACKNOWLEDGMENTS}

This work was supported by LPPM Director and all staff of Tarumanagara University, also to the Dean and Staff of the Faculty of Economics and Business, Universitas Tarumanagara.

\section{REFERENCES}

[1] Abayomi, S. O. (2016). Personal Ethics and Fraudster Motivation: The Missing Link in Fraud Triangle and Fraud Diamond Theories. International Journal of Academic Research in Business and Social Sciences, 6(2), 159-165. doi:10.6007/IJARBSS/v6-i2/2020

[2] ACFE. (2020). Report to the Nations 2020 Global Study on Occupational Fradud and Abuse. Austin, Texas: Association of Certified Fraud Examiners. Accessed from https://www.acfe.com/

[3] ACFE Indonesia Chapter. (2020, Mei). Survei Fraud Indonesia 2019. Accessed September 17, 2020, from www.acfe-indonesia.or.id
[4] Anfas, Mahdi, S. A., \& Umasugi, M. (2019.). The Effect of Fraud Diamond Theory and Level of Religiosity toward Academic Fraud to Undergraduate Students. International Journal of Arts and Social Science, 2(4), 42-51. Accessed from www.ijassjournal. com

[5] Bonsu, O. A., Dui, L., Muyun, Z., Asare, E. K., \& Amankwaa, I. A. (2018). Corporate Fraud: Causes, Effects, and Deterrence on Financial Institutions in Ghana. European Scientific Journal October 2018 edition Vol.14, No.28 ISSN: 1857 - 7881 (Print) e - ISSN 1857- 7431, 14(28), 315-335. DOI: 10.19044/esj.2018. v14n28p315

[6] CFI. (2020). What is the Fraud Triangle? Diambil kembali dari CFI Inc: https://corporatefinanceinstitute. com/resources/knowledge/accounting/fraud-triangle/

[7] Christian, N., Basri, Y., \& Arafah, W. (2019). Analysis of Fraud Triangle, Fraud Diamond and Fraud Pentagon Theory to Detecting Corporate Fraud in Indonesia. The International Journal of Business Management and Technology, 3(4), 73-78.

[8] Evana, E., Metalia, M., Mirfazli, E., Georgieva, D. V., \& Sastrodiharjo, I. (2019). Business Ethics in Providing Financial Statements: The Testing of Fraud Pentagon Theory on the Manufacturing Sector in Indonesia. Business Ethics and Leadership, Volume 3, Issue 3, 2019, 3(3), 68-77. Accessed from http://doi.org/ $10.21272 / \mathrm{bel} .3(3) .68-77.2019$

[9] Ergina, E., \& Erturanb, İ. E. (2019). Fraud Evasion Triangle: Why Can Fraud Not Be Detected? Journal of Accounting, Finance and Auditing Studies, 5(4), 35-45. DOI: $10.32602 /$ jafas. 2019.36

[10] Fernandhytia, F., \& Muslichah. (2020, January). The Effect of Internal Control, Individual Morality and Ethical Value on Accounting Fraud Tendency. Media Ekonomi dan Manajemen, Volume 35 Issue 1, January 2020, 112-127, 35(1), 112-127. DOI: http://dx.doi.org/ $10.24856 /$ mem.v35i1.1343

[11] Ghozali, I. (2009). Aplikasi Analisis Multivariat dengan Program SPSS. Semarang: Badan Penerbit Universitas Diponegoro.

[12] Homer, E. M. (2020). Testing the fraud triangle: a systematic review. Journal of Financial Crime, 27(1), 172-187. DOI: 10.1108/JFC-12-2018-0136

[13] Istifadah, R. U., \& Senjani, Y. P. (2020). Religiosity as the moderating effect of diamond fraud and personal ethics on fraud tendencies. Journal of Islamic 
Accounting and Finance Research, 2(1), 91-116. DOI: https://dx.doi.org/10.21580/jiafr.2020.2.1.4721

[14] Machado, M. R., \& Gartner, I. R. (2017, June 6). The Cressey hypothesis (1953) and an investigation into the occurrence of corporate fraud: an empirical analysis conducted in Brazilian banking institutions. R. Cont. Fin. - USP, 1-22. DOI: 10.1590/1808-057x201803270

[15] Malimage, K. (2019). Application of Underutilized Theories in Fraud Research: Suggestions for Future Research. Journal of Forensic and Investigative Accounting, 11(1), 33-49.

[16] Maria, E., \& Gudono. (2017). Empirical Test of Fraud Triangle Theory on Local Government (Evidence from Indonesia). International Journal of Applied Business and Economic Research, 15(4), 233-248. Accessed from http: www.serialsjournal.com

[17] Muhsin, Kardoyo, \& Nurkhin, A. (2018). What Determinants of Academic Fraud Behavior? From Fraud Triangle to Fraud Pentagon Perspective. ICE-BEES 2018. 2018, hal. 154-167. Semarang Indonesia: Knowledge E. DOI 10.18502/kss.v3i10.3126

[18] Purnamasaria, P., \& Amaliah, I. (2015). Fraud prevention: relevance to religiosity and spirituality in the workplace. 2nd Global Conference on Business and Social Science-2015 (hal. 827-835). Denpasar Bali: Elsevier Ltd. Accessed from online at www. sciencedirect.com

[19] Ramadhan, D. (2020). Root Cause Analysis Using Fraud Pentagon Theory Approach (A Conceptual Framework). Asia Pacific Fraud Journal, 5(1), 118-125. DOI: 10.21532/apfjournal.v5i1.142

[20] Said, J., Karim, Z. A., Alam, M. M., \& Johari, R. J. (2018). Integrating Religiosity into Fraud Triangle Theory: Findings on Malaysian Police Officers. Journal of Criminological Research, Policy and Practice, 4(2), 111-123. Accessed from https://doi.org/10.1108/ JCRPP-09-2017-0027

[21] Said, J., Alam, M. M., Ramli, M., \& Rafidi, M. (2017). Integrating ethical values into Integrating ethical values into fraud triangle theory in assessing employee fraud: Evidence from the Malaysian banking industry. Journal of International Studies, 10(2), 170-184. DOI: 10.14254/2071-8330.2017/10-2/13

[22] Sujana, E., Yasa, I. P., \& Wahyuni, M. A. (2019). Testing of Fraud Diamond Theory Based on Lo Wisdom on Fraud Behavior. 3rd International Conference on Tourism, Economics, Accounting, Management, and Social Science (TEAMS 2018) (pp. 12-15). Bali
Indonesia: Atlantis Press. Accessed from (http:// creativecommons.org/licenses/by-nc/4.0/)

[23] Sujeewa, G. M., Yajid, M. S., Khatibi, A., Azam, S. F., \& Dharmara, I. (2018, August). The New Fraud Triangle Theory - Integrating Ethical Values of Employees. International Journal of Business, Economics and Law, Vol. 16, Issue 5 (August), 16(5), 5257.

[24] The Institute of Internal Auditors. (2019, January 1). Fraud and Internal Audit- Assurance over Fraud Controls Fundamental to Success. Accessed from The Institute of Internal Auditors Global: www.globaliia.org

[25] Thomas, J. E. (2017). Scholarly Views on Theory: Its Nature, Practical Application, and Relation to World View in Business Research. International Journal of Business and Management, 12(9), 231-240. DOI: 10. 5539/ijbm.v12n9p231

[26] Vousinas, G. L. (2019). Advancing theory of fraud: The S.C.O.R.E. Model. Journal of Financial Crime, 26(1), 372-281. Accessed from https://www. emeraldinsight.com/doi/full/10.1108/JFC-12-20170128 